ISLAMIC BANKING: Jurnal Pemikiran dan Pengembangan Perbankan Syariah, Volume 7 Nomor 2 Edisi Februari 2022

\title{
APPLICATION OF THE CONCEPT OF ASSET AND LIABILITY MANAGEMENT (ALMA) IN THE ISLAMIC BANKING SYSTEM.
}

\author{
Choirunnisak \\ Sekolah Tinggi Ekonomi dan Bisnis Syariah (STEBIS) Indo Global Mandiri \\ Email: choirunnisak_umar@stebisigm.ac.id
}

\begin{abstract}
This study discusses the application of the concept of asset and liability management (ALMA) in the banking system. The method used in this research is library research with a qualitative approach, where the data are obtained from books, journals, articles and the like that discuss the theme. After that, it was validated, and analyzed descriptively. The results of this study are: Application of Asset and Liability Management in banking institutions, both Islamic banks and conventional banks must go through an assessment of the budget, make income plans, evaluate investment performance in the past, unify the distribution of bank assets and liabilities and implement asset and financial strategies. obligation
\end{abstract}

Keywords: Management, Assets, Liabilities, Islamic Bank

\begin{abstract}
Abstrak
Penelitian ini membahas tentang penerapan konsep asset and liability managemen (ALMA) dalam sistim perbankan. Metode yang dipakai pada penelitian ini adalah penelitian kepustakaan dengan pendekatan kualitatif, di mana data-datanya di dapatkan dari buku, jurnal, artikel dan sejenisnya yang membahas tentang tema tersebut. Setelah itu, di validasi, dan dianalisis secara deskriptif. Hasil dari penelitian ini yaitu: Penerapan Asset and Liabilitas Management pada lembaga perbankan, baik itu bank syariah maupun bank konvensional harus melalui tahap penilaian terhadap budget, membuat rencana pendapatan, penilaian kinerja investasi pada masa lalu, memantau distribusi aset dan liabilitas bank dan menerapkan strategi aset dan liabilitas
\end{abstract}

Kata Kunci; Manajemen, Asset, Liabilitas, Bank Syariah

\section{Introduction}

Discussing the asset management system cannot be separated from liability management. The two systems are like two sides of a coin that are connected. The reason is that most of the sources of Islamic bank assets are obtained from deposits, 
although Islamic banks have their capital their obligations are more dominant than their capital. As a result, the development of assets is affected by the increase in liabilities. As seen from the composition of the balance sheet of Islamic banks, the left side shows the assets owned, while the right side shows the obligations that must be fulfilled to stakeholders. To balance these two sides, Islamic banks need an effective and efficient management system. For this reason, Islamic banks implement Alma (Asset and Liability Management).

Asset and Liability Management is an activity to optimize the balance sheet structure of Islamic banks with various available alternatives1 to maximize profits while limiting risk to a minimum. The concept of Alma is not only applied to Islamic banking but has already been applied to conventional banks, even the concept is adoption of conventional theory. Of course, the suitability of this is still questionable, especially for Islamic banks to fully adopt the Alma concept. Therefore, this study is described to discuss the Implementation of Sharia Banking Asset And Liability Management.

This research is a type of library research (library research) that focuses on qualitative data management with data analysis methods using descriptive-analytical methods. This study aims to describe or reveal what is happening now (Arikunto, 2002), and explore phenomena that cannot be quantified (Satori and Komariah, 2009). In addition, descriptive is important because it is a data analysis method that serves to explain a thought (fact) so that it can be accepted rationally (Surabaya, 2007).

\section{Literature Review}

Research conducted by Nia Noviana Dwi Kharisma and Arivatu Ni'mati Rahmatika with the title Asset and Liability Management in Indonesian Islamic banks (Comparative Study Before and After the Marger). obtain greater profits in a way that is lawful for customers, without suffocating. Therefore, this study was conducted to determine the alma of Islamic banks in Indonesia before and after the merger. This research was conducted on three large banks that have merged into one, namely Bank Syariah Indonesia with a qualitative method, collecting data through literature study, namely literature study. In the management of Liquidity and Capital Management in conventional banks, the value is greater than the management of Liquidity in Islamic 
ISLAMIC BANKING: Jurnal Pemikiran dan Pengembangan Perbankan Syariah, Volume 7 Nomor 2 Edisi Februari 2022

banks. Meanwhile, in asset and liability management, in price management, Islamic banks have a higher level of price management than conventional banks. Post-merger in Indonesian Islamic banks is a very significant determining factor., because if there is an accumulation of optimal input, it is expected to provide maximum output as well so that efficiency occurs. On February 1, at the beginning of its operations, BSI was able to become a magnet for business players and investors in the stock market as indicated by a significant increase in share value. Until December 2020, BSI's assets have reached Rp.239.56 trillion.

Rifki Fajri Febrian The Role of Asset And Liability Management (ALMA) in Maintaining Stable Liquidity Levels at PT Bank BNI SYARIAH SCRIPTION Proposed Study Program of Sharia Banking Management Fajri Febrian Faculty of Islamic Religion Universitas Muhammadiyah Jakarta 1441 H / 2019 M. The results show that the implementation of Asset and Liability Management at BNI Syariah is carried out based on sharia principles and refers to the regulations of the Financial Services Authority (OJK). Management uses 2 approaches or methods, namely the Pool of Fund Approach and the Asset Allocation Approach. However, it is more dominant to use the Pool of Fund Approach method. The role of Asset and Liability Management at BNI Syariah is divided into 2 sides, namely the role on the asset side and the liability side. These assets and liabilities play an important role in maintaining liquidity and obtaining optimal income so that the health of the bank is maintained.

\section{Results and Discussion}

\section{Asset Management}

In the management of wealth, special and specific management knowledge is needed in managing wealth (assets) as it is known that many assets are not optimal in their utilization. For now, in Indonesia, the management of physical assets has not been implemented properly. Not only companies but also the government, seeing the potential that must be managed, asset management is very specific in managing and managing wealth. For example, many regional assets do not provide maximum profit or benefit. 
Asset management is defined as a process of managing assets (wealth) both tangible and intangible which have economic value, commercial value, and exchange value that can encourage the achievement of individual and organizational goals. Through the management process of smoothing, organizing, leading, and controlling which aims to gain profits and reduce costs effectively and efficiently.

\section{Liability Management}

The concept of liability management is the bank's ability to provide sufficient to meet all its obligations and commitments that have been issued to customers. Management of reserve requirements (RR) or primary reserves (PR) or minimum statutory reserves (GWM) by BI and secondary reserve (SR) regulations. Risks that can arise in liability management are funding risk and interest risk.

To assess the impact of liability management on bank profitability, the difference between an increase in income on an asset portfolio and an increase in the cost of borrowing funds from the open market must be analyzed. The increase in income from the asset portfolio was due to the increased concentration of assets on high-yield loans. The increased cost of ensuring liquidity through borrowed funds results from the market interest that must be paid on these funds. The spread between the increase in income from assets over liabilities is a measure of the change in interest margin.

A bank that ensures funds with loans must pay market interest rates. The cost of these funds is more volatile than the source of funds from a deposit, which could potentially result in increased variation in bank profits. The impact of using liability management on bank profits depends on the characteristics of the assets funded by borrowed funds. If a bank uses borrowed funds to support long-term loans with fixed interest rates, the bank's profits will vary according to variations in market interest rates. If a bank uses borrowed funds to fund assets whose income also fluctuates according to market interest rates, it will not have an impact on profits (Aravik \& Hamzani, 2021).

Increased confidence in liability management has reduced liquidity pressures and allowed banks to use larger percentages of funds for their higher-yielding assets. At the same time, the increasing use of borrowed funds has complicated the process of managing the bank's portfolio. To ensure profitability and minimize risk, banks must 
ISLAMIC BANKING: Jurnal Pemikiran dan Pengembangan Perbankan Syariah, Volume 7 Nomor 2 Edisi Februari 2022

simultaneously manage maturity, rate, and volume characteristics in their portfolio of assets and liabilities. (Ismail Nawawi: 2014)

\section{Asset and Liability Management}

Asset and Liability Management is a set of actions and procedures designed to control financial position. Safety and health issues are an important part of this definition. However, the Credit Cooperative recognizes the need for consistent income to support growth and services, in balance with other factors. Thus, the purpose of Asset and Liability Management is to maintain the health of banks which can be measured by CAMEL, and to anticipate external changes related to inflation and interest rates as well as changes in currency exchange rates (M Ali 2004) in addition to Asset and Liability Management. it is intended that banks obtain optimal net income for banks with proper control over assets and passive banks are expected to be able to earn income from these activities.

In studying Asset and Liability Management, there are several risk categories, which are as follows:

a. Risk in the field of credit.

b. Risk in the field of Liquidity (banks cannot pay their obligations on time or can only pay by making emergency loans or selling assets.

c. Interest rate risk (Risk due to changes in interest rates)

d. Foreign exchange risk (loss due to exchange rate changes)

e. Risk in the contingent sector (risk due to contingent transactions)

For the above risks to be minimized, an Asset and Liability Management process framework is needed that is designed in such a way as to maximize profits while limiting asset and liability risks by complying with the provisions of monetary policy and bank supervision. A strong Asset and Liability Management (Alma) will provide a clear foundation covering management strategy, support, and implementation of bank development. Therefore, it is necessary to form a framework for Asset and Liability Management (Alma) in the following order:

1) The establishment of Asset and Liability Management (Alma) policies and 
strategies by organizations that have formal authority and professional personnel

2) There is a goal/direction for management and implementing officers in the process of carrying out their duties by setting certain standards.

3) The existence of internal/external data collection ensures that the data collected is sufficient to support Asset and Liability Management decisions both for the short and long term.

4) There is an analysis that develops scenarios to test various alternative Asset and Liability Management strategies before decisions are made and officers monitor the effectiveness of these implementations

5) The existence of liquidity management that can manage funds properly at a reasonable interest rate, to fulfill every obligation and take advantage of new opportunities.

6) The existence of gap management that aims to maximize income and minimize risk, which is associated with the size of the gap/mismatch

7) There is a foreign exchange management that manages the gap between each currency and between currencies listed in the bank's books to generate maximum profit within certain risk limits.

The existence of pricing management ensures that the interest rate-setting strategy can support the implementation process of gap management, liquidity, and foreign exchange management. Then to implement the Asset and Liability Management framework above, it is necessary to form an Asset and Liability Management organization in a bank. The Asset and Liability Management Organization (Alma) of a bank generally consists of the Asset Liability Committee (ALCO) or other organizational units that have the same formal rights as ALCO and the ALCO Support Group (ASG). Within the organization, ALCO's responsibilities are set, namely setting goals, making Asset and Liability Management decisions, monitoring activities, and reviewing the results of Asset and Liability Management policies. Meanwhile, ASG's responsibilities are to collect internal and external data, compile analysis, develop strategies and scenarios, make 
ISLAMIC BANKING: Jurnal Pemikiran dan Pengembangan Perbankan Syariah, Volume 7 Nomor 2 Edisi Februari 2022

reports, submit suggestions for ALCO meetings and monitor their implementation. The process of making Asset and Liability Management policies is carried out by the bank's directors. The policies referred to include setting limits and targets for each sector, ratios of funding and investment strategies, balance sheet structure, pricing policies, capital requirements, etc.

\section{Asset and Liability Management Function (ALMA)}

To make it easier and easier to understand the tasks of Asset and Liability Management (Alma), the following discussion will explain the main functions contained in Asset and Liability Management (Alma), namely:

a. Liquidity Management

Liquidity management is the ability of bank management to provide sufficient funds to meet all obligations and commitments that have been issued to its customers at any time. The liquidity management is carried out to fulfill the following tasks:

1). Ability to predict future funding needs.

2). Find a source of funds to meet the required amount.

3). Administering incoming and outgoing funds.

Furthermore, in managing bank liquidity, several risks may arise, including the following:

a. Funding risk. This risk arises when the bank does not have enough funds to meet its obligations.

b. Interest risk. The existence of various variations in interest rates in assets and liabilities can cause uncertainty about the level of profit that will be obtained.

Several Bank Liquidity Measuring Instruments, in the concept of Asset and Liability Management (ALMA) the measurement of bank liquidity is carried out for both short and long term. For short-term measurements, among others are used:

1) Statutory Reserve Requirements, known as minimum statutory reserves (GWM), namely Demand Deposits at > 5\% Liability to third parties in the previous two-week period. To meet the GWM, a minimum of 5\% of thirdparty funds is required, while the amount of physical cash needed for daily 
340 Choirunnisak, Application Of The Concept Of Asset And Liability.......

operations is left to the policies of each bank and this depends on the amount of cash that is needed, oh bank. Thus, the bank's primary reserve will always be above $5 \%$ of third-party funds, namely in the form of 5\% Statutory Reserves plus physical cash in the safes of each branch.

2) Basic Surplus, which is a measurement of the amount of liquidity in a certain condition as measured by the formula: Basic Surplus = Current Assets Current Pasivates Classification of basic surplus numbers:

a) Positive: Short-term placements are supported by long-term funding sources

b) Negative: Long-term fund placement is supported by short-term funding sources

c) Zero: Short-term fund placements are supported by short-term funding sources.

Furthermore, to measure long-term liquidity (long-term liquidity) measuring instruments can be used, including:

1. Liquidity Ratio $=$ New purchased funds required Total funding requirement This tool is used to measure the projection of bank liquidity needs after calculating the desired business within a certain period. New purchased funds are required, namely the projected changes in assets minus the projected changes in liabilities on the bank's balance sheet. Meanwhile, the total funding requirement is the number of funds (liabilities) needed on a certain date in the future to finance assets.

2. Indeks Likuiditas. Liquidity Index $=$ Total weighted liabilities Total weighted assets 
ISLAMIC BANKING: Jurnal Pemikiran dan Pengembangan Perbankan Syariah, Volume 7 Nomor 2 Edisi Februari 2022

This tool is used to measure liquidity conditions for a longer period at a certain time. Before performing the calculations, the components of the assets and liabilities of the balance sheet are classified as in the basic plus calculation. The difference in each time group is given weight with a greater weight for a longer classification period.

b. Loan to Deposit Ratio (LDR)

Comparison of the number of loans disbursed with public deposits is formulated as follows: $\mathrm{LDR}=$ Loans disbursed by public funds By Bank Indonesia regulations, a bank's liquidity level is considered healthy if its LDR is between $85 \%-110 \%$.

Tabel.1.1

Sharia Bank Asset Classification

\begin{tabular}{|c|c|c|}
\hline No & Types of Assets & Description \\
\hline 1 & \begin{tabular}{|l} 
Current assets \\
a. Cash \\
b. Current Account with Bank \\
Indonesia \\
c. Current Accounts with Other \\
Banks \\
d. Securities
\end{tabular} & $\begin{array}{l}\text { Can be found whenever needed } \\
\text { and is usually used to maintain } \\
\text { the liquidity of Islamic banks }\end{array}$ \\
\hline 2 & $\begin{array}{l}\text { Substandard Assets5 } \\
\text { a. Murabaha. Receivables } \\
\text { b. Greetings } \\
\text { c. Istishna' Receivables } \\
\text { d. Ijarah Receivable } \\
\text { e. Mudharabah Financing } \\
\text { f. Musharaka Financing } \\
\text { g. Inventory (Items for Sale) } \\
\text { h. Bills and Liability Expectations } \\
\text { i. Istishna's Assets in Completion } \\
\text { j. Deferred Tax Assets }\end{array}$ & $\begin{array}{l}\text { Assets that provide benefits for } \\
\text { more than } 1 \text { year and } \\
\text { the disbursement cannot be done } \\
\text { in a short time because it is } \\
\text { related to a third party. }\end{array}$ \\
\hline 3 & Fixed assets & Tangible assets \\
\hline
\end{tabular}




\begin{tabular}{|l|l|l|}
\hline $\begin{array}{l}\text { a. Ijarah Assets } \\
\text { b. Other Fixed Assets }\end{array}$ & $\begin{array}{l}\text { And can } \\
\text { used in the long term, such as } \\
\text { buildings, land, office equipment, and } \\
\text { others. }\end{array}$ \\
\hline
\end{tabular}

Based on the types of assets, it can be concluded that the assets in Islamic banks are not seen from the source but rather emphasize the benefits derived from these assets. In other words, assets that are recognized in Islamic banks are assets that have been controlled, have been channeled in the form of financing, and assets that are being enjoyed.

\section{Sharia Bank Asset Management}

The implementation of Asset and Liability Management in banking institutions, both Islamic banks, and conventional banks must go through the stages of assessing the budget, making income plans, evaluating past investment performance, monitoring the distribution of bank assets and liabilities, and implementing asset and liability strategies. (Zainul Arifin.,2006)

More specifically, the following describes the implementation of these stages in Islamic banking:

\section{a) Budget assessment}

At this stage, Islamic banks make financial planning related to funds that can be used for investment (Aravik, 2016). In other words, Islamic banks assess several funds that are available or not available either from the sale of shares, Third Party Funds (DPK), or loan funds from other parties. The purpose of this assessment is to help Islamic banks see the potential for funds that can be obtained and make it easier for banks to make capital budgeting plans. The funds commonly used by Islamic banks are as follows: (Sri Nurhayati, Akuna. 102) 
ISLAMIC BANKING: Jurnal Pemikiran dan Pengembangan Perbankan Syariah, Volume 7 Nomor 2 Edisi Februari 2022

Picture 1.2 Islamic Bank Fund Source

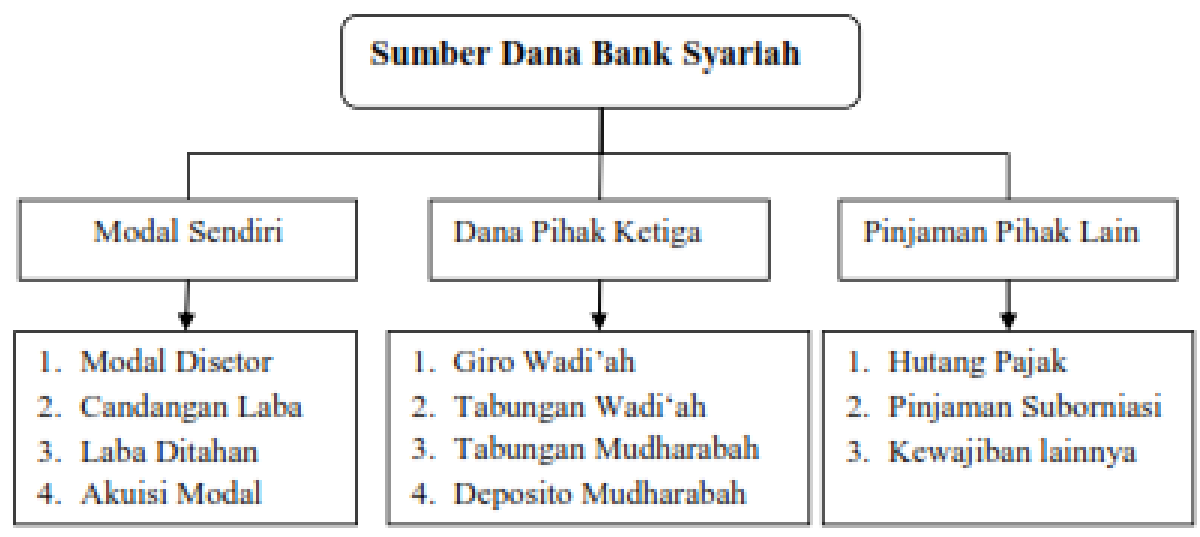

b) Making an Income Plan

This stage intends to create a revenue target that Islamic banks want to obtain in the next year. This target is closely related to the sources of funds and the ability of Islamic banks. Usually, this revenue target will be charged to each accounting officer as an employee who is directly related to investment instruments. Whether or not this target is achieved depends again on their performance in the field.

c) Assessment of Investment Performance in the Past

Assessment of investment performance in the past is intended for Islamic banks to predict the possibilities that will occur for all policies taken by the bank. By looking at past performance, the bank can make several programs that will be completed in the future by the capabilities that have been analyzed through financial statements as a reflection of the bank's success. In addition, banks can also know the risks that may be faced in the future, so that they can be minimized or anticipated as early as possible.

d) Monitoring the Distribution of Bank Assets and Liabilities

In the fourth stage, the bank monitors the remaining assets that can be used for the future. The purpose of the remaining assets is several funds, whether in the form of cash, receivables, financing, or other forms that are due or near maturity so that these funds can be used for further investments. Meanwhile, the purpose of observing bank liabilities is to assess and measure several loan funds with long maturities. This can be 
used to manage these funds by channeling them into various profitable investment instruments.

e) Implementing the Asset and Liability Strategy

At this stage, the bank will carry out the above planning by combining assets and liabilities. For example, Islamic banks make financial plans by combining $60 \%$ of their capital, $30 \%$ of third-party funds, and $10 \%$ of loans from other parties. With this composition, Islamic banks will assess how much profit will be obtained if the source of these funds is invested. This composition is made to assess the costs incurred for each source of funds used. Therefore, Islamic banks will make various compositions of funds to measure the level of costs and the level of profitability that will be obtained.

Likewise with investment combinations, for example, Islamic banks make plans to budget their funds to various investment instruments with a fixed return investment composition (financing using a buying and selling system) of 50\%, investment (mudharabah and Masyarakat) of 20\%, and purchase of securities from money market by $10 \%$. The choice of this type of investment will then be assessed for the probability of profit and risk that must be borne. After making various combinations and assessing the best and worst possibilities, Islamic banks then choose which asset and liability strategies can achieve the revenue targets that have been set. A series of steps above are applied in Asset and Liability Management. The focus of the application of ALMA in Islamic banks is to coordinate the portfolio of assets and liabilities to maximize profits for the bank and profit sharing for shareholders while still paying attention to liquidity needs and prudential principles. (Zainul Arifin., 2009).

In the application of this theory, Islamic banks must form a unit that works together to carry out a mutually agreed plan. This unit is called the Asset and Liability Management Committee (ALCO). The unit consists of the President Director and key managers who are active in financing, investment, and money market decisions. Usually, these activities are carried out by the head of finance and accounting, to the Financing Division, Investment Manager and Head of Deposit, Economist, and Financing Policy Supervisor. The parties involved have the same goal, namely minimizing risk and ensuring the availability of sufficient liquidity. (Antonio., 2001) 
ISLAMIC BANKING: Jurnal Pemikiran dan Pengembangan Perbankan Syariah, Volume 7 Nomor 2 Edisi Februari 2022

So that all sections work simultaneously to improve the quality of assets owned to attract potential investors and customers to invest in Islamic banks. ALCO's duties in Islamic banks can be broadly classified

Islamic banking investment. This task is related to investment decisions that have been planned in the financial plan (budgeting). The purpose of the investment decision is the entire process of planning and making decisions regarding the expenditure of funds to benefit from the investment in the form of profits. While the planning in question is a target or target that has been set to be achieved within 1 year, six months, or three months. (Najmuddin., 2011)

\section{Implementation Of Asset And Liability Management In Sharia Banking}

Islamic bank asset management cannot be separated from liability management because the two are interconnected where the source of Islamic bank assets mostly comes from liabilities (liabilities) in the form of Third Party Funds. This is an implication of the system used by Islamic banks, namely the wadi'ah and mudharabah mutlaqah systems. These two systems are used to collect funds from customers to develop bank assets. The system is applied to the following products:

a. Wadi'ah Savings

Wadi'ah deposits consist of two main products, namely current accounts, and savings products. Giro is a bank product in the form of savings that can be withdrawn at any time, either by cheque, billet giro, other means of payment orders, or book entry. (Kasmir., 2010).

It is different with savings products, namely deposits where withdrawals can only be made using a passbook, withdrawal slip, receipt, or using an Automated Teller Machine (ATM). (cashmere.,2010)

Although these two products use the wadi'ah principle, the two products differ in terms of withdrawal flexibility. The current account product is more flexible than the savings product because the current account is very liquid compared to the savings account. The source of funds from the two products above cannot be freely used by Islamic banks due to the wadi'ah Riyadh dhamanah concept. This concept restricts 
Islamic banks from managing these funds, where the funds obtained are deposits that must be returned by the bank whenever the customer makes a withdrawal. In other words, these funds are more of an obligation (liability) whose integrity must be guaranteed. So that Islamic banks can only use these funds for liquidity needs or invest in low-risk businesses, such as Murabahah, Salam, and Istishna financing (ascarya.,2013).

The advantage of using this system is that Islamic banks do not need to pay expensive fees because the bonuses given depend on the bank's policy and the bonus does not have to be given to customers. To see the operational system of the Rabi'ah Riyadh dhmanah principle in Islamic banks, the following scheme is described for its implementation:

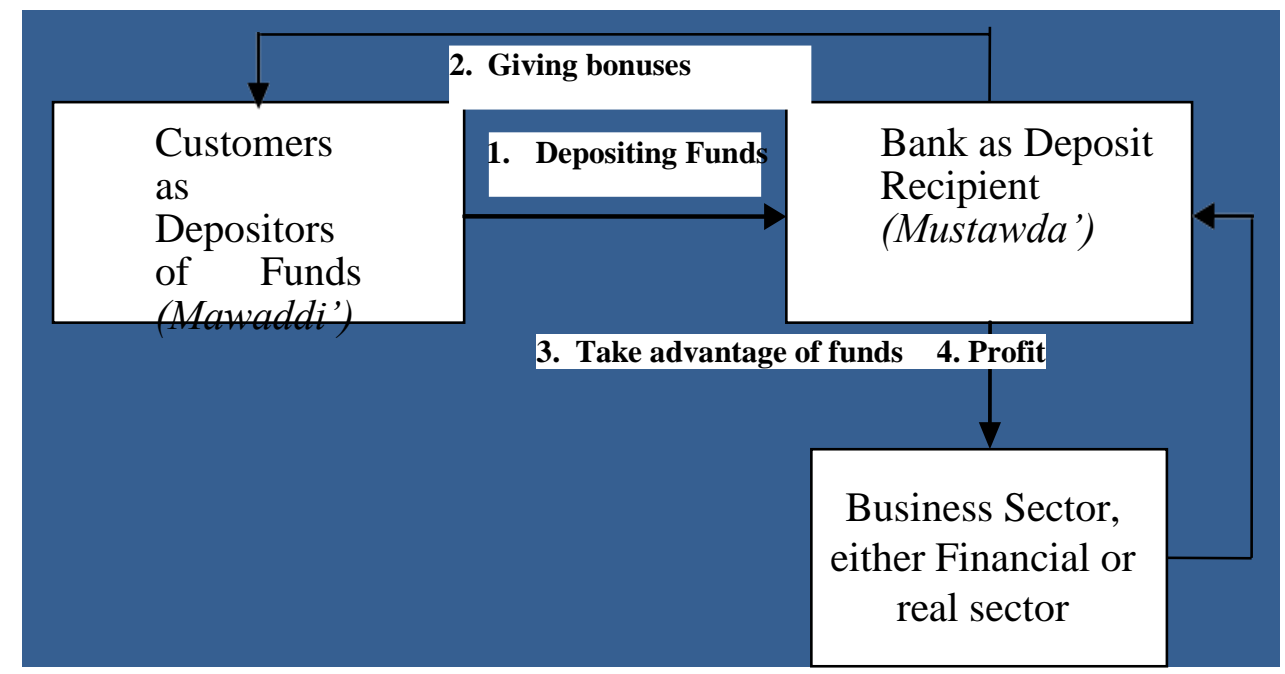

b. Mudharabah Investment

Mudharabah investment in Islamic banking is applied to savings and deposit products. These two products usually use the concept of mudharabah mutlaqah, but they differ in terms of withdrawal. Savings products with the mudharabah principle are no different from Madinah savings products in terms of the means of withdrawal. But this savings is a customer investment to a bank, where the customer fully surrenders the management of his funds to investments that are lawful and profitable. This product is not compatible with the mudharabah principle because the deposit can be withdrawn at 
ISLAMIC BANKING: Jurnal Pemikiran dan Pengembangan Perbankan Syariah, Volume 7 Nomor 2 Edisi Februari 2022

any time by the customer. So if a bank uses this product for investment, it must have sufficient liquidity reserves to fulfill withdrawal transactions from customers. This is different from the mudharabah deposit product, where the bank knows exactly when the maturity of the deposit it receives. So that banks can use these funds more freely without fear of lack of liquidity.

The two products above do not have any costs for Islamic banks because profit sharing is only given if the bank makes a profit from the funds invested by the agreed ratio. The scheme for implementing the concept of mudharabah mutlaqah in Islamic banks is as follows:

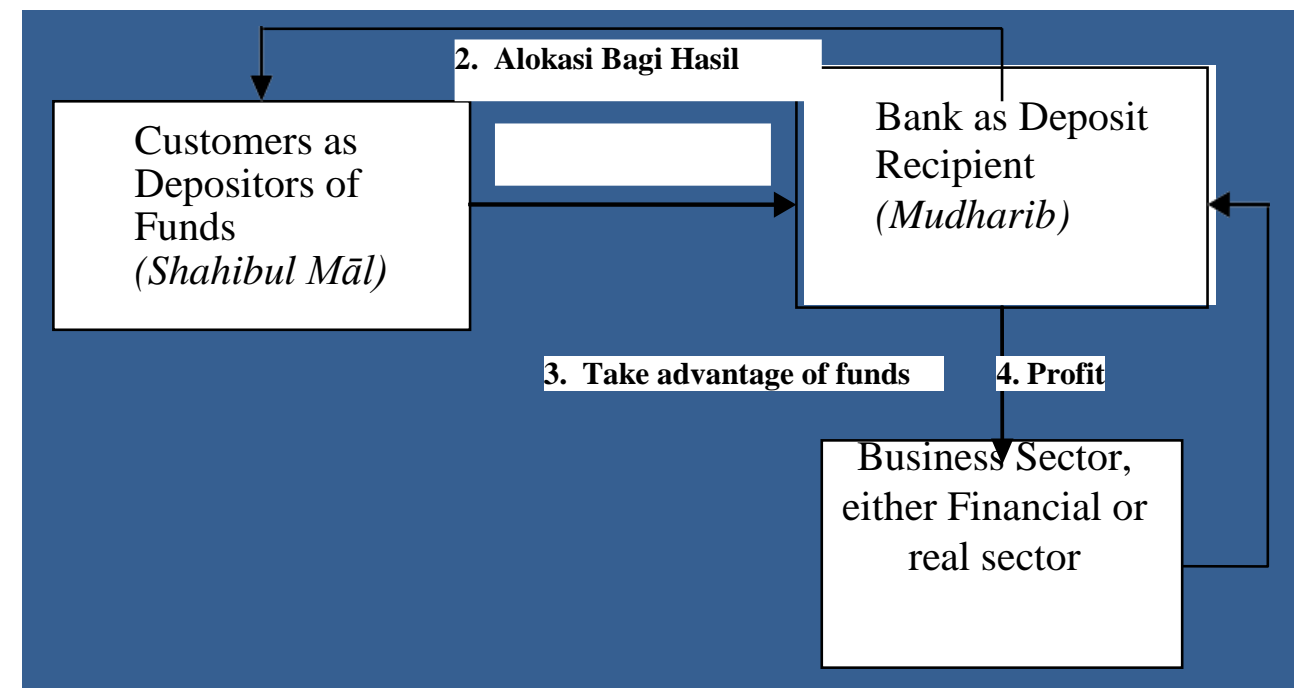

In addition to the mudharabah principle above, Islamic banks also use the mudharabah muqayyadah principle in deposit products. The use of the principle limits the authority of the bank in terms of managing funds, where the customer sets a condition that the funds must be invested in the business sector targeted by the customer. Therefore, the bank separates these funds from other Third Party Funds (almudharabah muqayyadah off-balance sheet). But the bank can also pool the funds if the customer does not require the separation of the funds (mudharabah muqayyadah on the balance sheet). (muhammad., 2005)

Based on the three concepts above, be it Rabi'ah Riyadh dhamanah, mudharabah mutlaqah, and mudharabah muqayyadah, it can be seen that Islamic bank assets do not incur fixed costs like conventional banks. Furthermore, the concept of fees at 
conventional banks is not by the concept of return on deposits provided by Islamic banks because fees at conventional banks are fixed and have been determined in advance, while bonuses are bank appreciations that can be given or waived depending on the bank's policy. Likewise, with profit sharing, profit sharing cannot be said to be a cost because it is the right of the customer which is only obtained if the funds make a profit. If the opposite happens, the customer has no right to demand anything from the management of his funds.

If you listen to the concept of mudharabah above, it can be concluded that the funds obtained from mudharabah are in the form of customer investments in Islamic banks. If it is an investment, the Islamic bank is not obliged to return the funds, in other words, the bank does not need to guarantee the funds. However, the majority of Islamic banks are currently required to guarantee the return of the Third Party Funds they receive. This is because Islamic banks use a revenue-sharing system instead of profit and loss-sharing. The implication of using the revenue sharing system is that Islamic banks do not consider the costs associated with the management of Third Party Funds so that the bank distributes the income generated from its operations. In other words, the profit-sharing provided is in the form of income before deducting costs (gross profit). ( Rizal Yaya et al., 2014:

As a result, banks only share income before reducing costs, while the risk of loss is fully borne by Islamic banks as a result of the implementation of mudharabah mutlaqah and revenue sharing systems. For this reason, Third Party Funds are recognized as liabilities that must be returned by Islamic banks. This is the background of Islamic banks using the ALMA (Asset and Liability Management) theory in managing their assets.

The above reality makes Islamic banks continue to recognize all of their Third Party Funds as obligations that must be returned at each maturity or every withdrawal by the customer. Not all of the forms of funds collected by Islamic banks can be categorized as loans, but some of them are collected in the form of investments. This can be seen from the composition of the funds described above, namely the mudharabah principle. This principle requires banks to recognize the funds raised as investments, where the bank acts as the manager (mudharib), and the customer as the owner of the 
ISLAMIC BANKING: Jurnal Pemikiran dan Pengembangan Perbankan Syariah, Volume 7 Nomor 2 Edisi Februari 2022

funds (shahibul māl). However, in the practice of Islamic banking, these investment funds are treated as funds collected using the wadi'ah Riyadh dhamanah principle. Therefore, the use of ALMA is by the Islamic banking system, although in principle it cannot be fully enforced due to the uniqueness of the operational principles of Islamic banks which cannot be equated with conventional principles.

\section{Conclusion}

Islamic bank asset management cannot be separated from liability management because the two are interconnected where the source of Islamic bank assets mostly comes from liabilities (liabilities) in the form of Third Party Funds. This is an implication of the system used by Islamic banks, namely the wadi'ah and mudharabah mutlaqah systems. These two systems are used to collect funds from customers to develop bank assets. The system is applied to wadi'ah products, and Mudharabah investment.

\section{REFERENCES}

Aravik, H. (2016). Ekonomi Islam: Konsep, Teori dan Aplikasi serta Pandangan Pemikiran Ekonomi Islam dari Abu Ubaid sampai al-Maududi. Empat Dua Intranspublishing.

Aravik, H., \& Hamzani, A. I. (2021). Etika Perbankan Syariah: Teori dan Implementasi. Deepublish Arifin, Zainul, Dasar-dasar Manajemen Bank Syariah, Cet. VII, EdisiRevisi, Jakarta: Azkia, 2009.

Arikunto, Suharsimi (2010). Prosedur penelitian. Jakarta: Rineka Cipta.

Ascarya (2013), Akad dan Produk Bank Syariah. Cet. IV, Edisi 1. Jakarta:Rajawali Pers.

Kasmir, (2014). Dasar-dasar Perbankan, Cet. VIII. Jakarta: Rajawali Pers.

Muhammad. (2015) Manajemen Dana Bank Syari’ah. Yogyakarta: Ekonisia.

Najmudin, (2011). Manajemen Keuangan dan Aktualisasi Syariah Modern, Edisi I, Yogyakarta: Andi. 
350 Choirunnisak, Application Of The Concept Of Asset And Liability.......

Nawawi, Ismail. (2014). Manajemen Perbankan Syari'ah" teori, pengantar praktek dan isu-isu kontemporer perkembangan dan pengembangan industri Perbankan Syari'ah, VIV Press ,Jakarta 2014.

Nia Noviana Dwi Kharisma dkk, (2021). Asset and managemen di bank syariah (study komparatif sebelem dan sesudah marger). Journal of Education and managemen studies. Vol.4. Agustus 2021.

Nurdin, Ridwan, Muslina, (2016). Analisis Kesesuaian Konsep Asset and Liability Management (Alma) dengan SistemPerbankan Syariah. Mediah Syariah. V01.18. no.2 Juni-Des 2016

Sotari, Djam'an dan Aan Komariah. (2009). Metodelogi Penelitian Kualitatif. Bandung: PT. Alfabeta.

Syafii Antonio, Muhmmad. (2020). Bank Syari'ah dari Teori ke Praktek. Jakarta: Gema Insani.

Parmujianto. (2017). Integrasi Manajemen Asset dan Liabilitas Perbankan Syariah. Iqtishodana Vol. 6. No.1. April. 2017.

Yaya , Rizal dkk, (2014). Akuntansi Perbankan Syariah Teori dan Praktek Kontemperer Berdasarkan PAPSI, Edisi II, Jakarta: Salemba Empat. 